\title{
2021 Florida Plant Disease Management Guide: Eggplant ${ }^{1}$
}

\author{
Shouan Zhang, Geoffrey Meru, Ken Pernezny, and Aaron Palmateer ${ }^{2}$
}

\section{Specific Common Diseases}

\section{Bacterial Wilt (Ralstonia solanacearum)}

Symptoms: Plants wilt and die suddenly with slight or no leaf yellowing prior to death. Plants cut at the soil line will exhibit reddish-brown, slimy pith in cross-section. Bacterial ooze streaming can be observed from the vascular tissue when the lower stem section is suspended in a jar of water.

Cultural Controls: No economical controls are available for this disease. Avoid land with a previous history of this disease. Practice good sanitation to reduce the spread of the disease, including sanitizing of tools and equipment by spraying with a disinfectant after working in an infected field. Rotate out of susceptible solanaceous crops into grass, legume, or cucurbit crops.

\section{Damping-Off (Fusarium spp., Pythium spp., Rhizoctonia solani)}

Symptoms: Soil-borne pathogens such as Fusarium, Pythium, and Rhizoctonia species will infect newly planted seed through the seedling stage. These pathogens will feed off lateral roots and may rot the hypocotyl above or below ground causing seedling death.

Cultural Controls: Plant in well-drained sites when soil moisture and temperature are conducive to rapid seed germination and emergence. Do not plant in soil with a high percentage of recently incorporated, undecomposed plant debris. Employ a seed treatment fungicide and consider soil fumigation of seedbeds.

Chemical Controls: See PPP-6.

\section{Early Blight (Alternaria tomatophilia)}

Symptoms: Small, light-colored spots often occur on the leaves, with minimal concentric ringing characteristics of early blight. Very occasionally, leathery spots may be seen on fruit. Premature fruit drop may occur if fruit pedicels are infected. The incidence of early blight is often greater in the presence of mites.

Cultural Controls: Plant certified, disease-free eggplant seed. Plant as far from tomato and potato fields as possible. Remove the affected leaves. Thin the plants to allow for better airflow. Keep weeds out of the field. Fertilize and irrigate plants appropriately to promote plant health and better fruit growth.

Chemical Controls: See PPP-6.

\section{Phomopsis Blight (Phomopsis vexans)}

Symptoms: Seedlings exhibit dark brown lesions that become gray in the center and develop on the stem slightly above the soil line. The stem soon becomes girdled and the plant topples over and dies. On established plants, brown,

1. This document is PDMG-V3-39, one of a series of the Plant Pathology Department, UF/IFAS Extension. Original publication date July 1998. Revised December 2005 and January 2022. Visit the EDIS website at https://edis.ifas.ufl.edu for the currently supported version of this publication.

2. Shouan Zhang, professor, Plant Pathology Department; Geoffrey Meru, assistant professor, Horticultural Sciences Department, UF/IFAS Tropical Research and Education Center; Ken Pernezny, professor emeritus, Plant Pathology Department, UF/IFAS Everglades Research and Education Center; and Aaron Palmateer, principal technical specialist, Bayer Environmental Science; UF/IFAS Extension, Gainesville, FL 32611.

The Institute of Food and Agricultural Sciences (IFAS) is an Equal Opportunity Institution authorized to provide research, educational information and other services

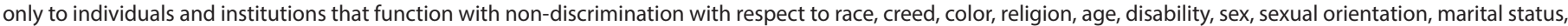

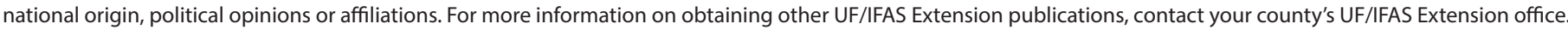
U.S. Department of Agriculture, UF/IFAS Extension Service, University of Florida, IFAS, Florida A \& M University Cooperative Extension Program, and Boards of County Commissioners Cooperating. Andra Johnson, dean for UF/IFAS Extension. 
round or oval spots may develop on the leaf and stem becoming irregular in shape as they enlarge. The center becomes gray and contains small black dots (pycnidia) while the margin is a narrow, dark brown zone. Foliar infection is minor compared to fruit infection. Fruit are infected while on the plant. The spots are pale, sunken areas and may finally cover the entire fruit. The small black pycnidia are present in abundance in the fruit spots.

Cultural Controls: 'Florida Market' and 'Florida Beauty' are resistant to the "tip over" stage of seedling blight, but the leaf and stem blight and fruit rot stages are still serious problems. Crop rotation with non-host plants may be beneficial in highly infected fields. Remove weeds since the pathogen can survive on solanaceous weeds such as nightshade. Maintain a fungicide program in the transplant bed. Only disease-free plants should be set into the field.

Chemical Controls: See PPP-6.

\section{Phytophthora Blight (Phytophthora capsici)}

Symptoms: Severe losses from this disease have been recorded in south Florida during wet winter vegetable seasons. This disease may attack eggplant roots, leaves, stems, or fruit. Symptoms include damping-off of young seedlings, spotting of lower leaves, and decay at the base of older stems. Advanced stem infection leads to wilting and collapse of the plants. Fruit may become infected at any time in their development. Individual fruit spots enlarge rapidly and significant portions of the fruit may become decayed and soft.

Cultural Controls: Avoiding excessive soil moisture is important for managing Phytophthora blight. Plastic mulch substantially reduces infection caused by spores of the pathogen splashed up onto fruit surfaces. Avoid planting eggplant following pepper, especially if the pepper had a confirmed outbreak of Phytophthora blight.

Chemical Controls:Use a pre-plant soil fumigant.

\section{Pythium Fruit Rot (Pythium spp.)}

Symptoms: The blossom end of the fruit bleaches white, and then turns tan and wrinkled. The flesh becomes watery and light brown in color. The white, cottony growth of the pathogen eventually covers the surface of the fruit, especially during moist periods.

Cultural Controls: Avoid excessive moisture and poorly drained areas in the field. Avoid fruit contact with the soil by using plastic mulch. Discard all fruits that show brown discoloration at harvest. The causal agent can spread by fruit-to-fruit contact and can contaminate harvesting containers.

\section{Southern Blight (Sclerotium rolfsii)}

Symptoms: This disease occurs during hot, moist weather. Plants exhibit a progressive wilt with leaf chlorosis and necrosis beginning with the lower leaves. The causal fungus infects the root system and stem at the soil line until the plant is killed. Fruit borne low on the plant may become infected.

The causal fungus becomes obvious as a coarse weft of white mycelium on the stem at the soil line during humid and wet weather. Small mustard-seed-sized fruiting structures (sclerotia) form on the mycelium. These are initially white, maturing to a tan color. These overseasoning structures fall to the soil and can survive for years under Florida conditions.

Cultural Controls: No economical controls exist for this disease under Florida conditions. Deep plowing infested land will reduce disease severity by burying sclerotia. Crop rotation with a non-host such as a grass crop is advised.

\section{Verticillium Wilt (Verticillium spp.)}

Symptoms: This wilt disease progresses slowly on eggplant. Plant vigor is adversely affected and the plant growth can be stunted. Lower foliage will become slight yellowing while plants exhibit progressive daily wilt until death. Slight vascular discoloration will be evident when lower stems are split lengthwise.

Cultural Controls: Do not crop land with a history of this soilborne fungal disease. Plant resistant varieties; choose non-susceptible rotation crops such as cucurbits, beans, or grasses. Solarize soil in the middle of summer to reduce the inoculum. 